\section{Nukleotider mot kreft}

\section{Antisense-nukleotider kan brukes til å deaktivere genuttrykk i maligne svulster.}

Store sekvenseringsstudier har vist hvordan genuttrykk kan endres i maligne svulster. STAT3 er en transkripsjonsfaktor som er oppregulert ved flere krefttyper, men det har vist seg vanskelig å inhibere transkripsjonsfaktorer terapeutisk.

En ny generasjon antisense-nukleotider er kjemisk modifisert med etylgrupper slik at de lettere tas opp i cellen. Omfattende screeningsstudier både in vitro og in vivo bekrefter at antisense-nukleotiden AZD9150 er en god kandidat for inhibering av STAT3 (1). Studiene viser at AZD9150 gir en doseavhengig nedregulering av STAT3 og redusert proliferering i lungekreftcellelinjer. Forsøk med xenograftmodeller viste inhibering av STAT3 målt på proteinnivå foruten redusert tumorvekst. I en fase I-studie med 25 kreftpasienter som ikke svarte på standardbehandling, oppnådde 11 pasienter stabil sykdom eller en delvis respons. Reduksjon av tumor ble observert hos noen pasienter.

- Dette er en spennende artikkel, som beskriver resultater fra laboratorieanalyser og klinisk utprøvning av et nytt medikament, sier overlege og forsker Åslaug Helland ved Oslo universitetssykehus, Radiumhospitalet. Hun leder Kreftforeningens nasjonale kompetansemiljø for lungekreft. - STAT3 spiller en rolle som pådriver i utviklingen av flere krefttyper, og forskningsgruppen ønsker å hemme denne transkripsjonsfaktoren og på den måten hemme kreftceller. Det er sjelden vi får presentert resultater som omfatter både cellelinjestudier, dyremodellstudier og klinisk utprøvning i én og samme originalartikkel, sier Helland.

I en doseeskaleringsstudie viste resultatene god klinisk respons hos både lymfompasienter og én lungekreftpasient. Disse hadde fått mye annen behandling tidligere. Det er derfor spesielt lovende at noen pasienter hadde svært god effekt av studiemedisinen, som selvsagt må testes ut på langt flere pasienter før man kan si noe om den kliniske nytten, sier Helland.

\section{Ruth Halsne}

Oslo

\section{Litteratur}

1. Hong D, Kurzrock R, Kim Y et al. AZD9150, a nextgeneration antisense oligonucleotide inhibitor of STAT3 with early vidence of clinical activity in lymphoma and lung cancer. Sci Transl Med 2015; 7: 314 ra185

\title{
Gir passiv røyking mer karies hos småbarn?
}

\author{
Barn som er eksponert for tobakksrøyk, har dobbelt så høy risiko for å få \\ karies enn dem som ikke er utsatt for røyk, ifølge en ny studie fra Japan.
}

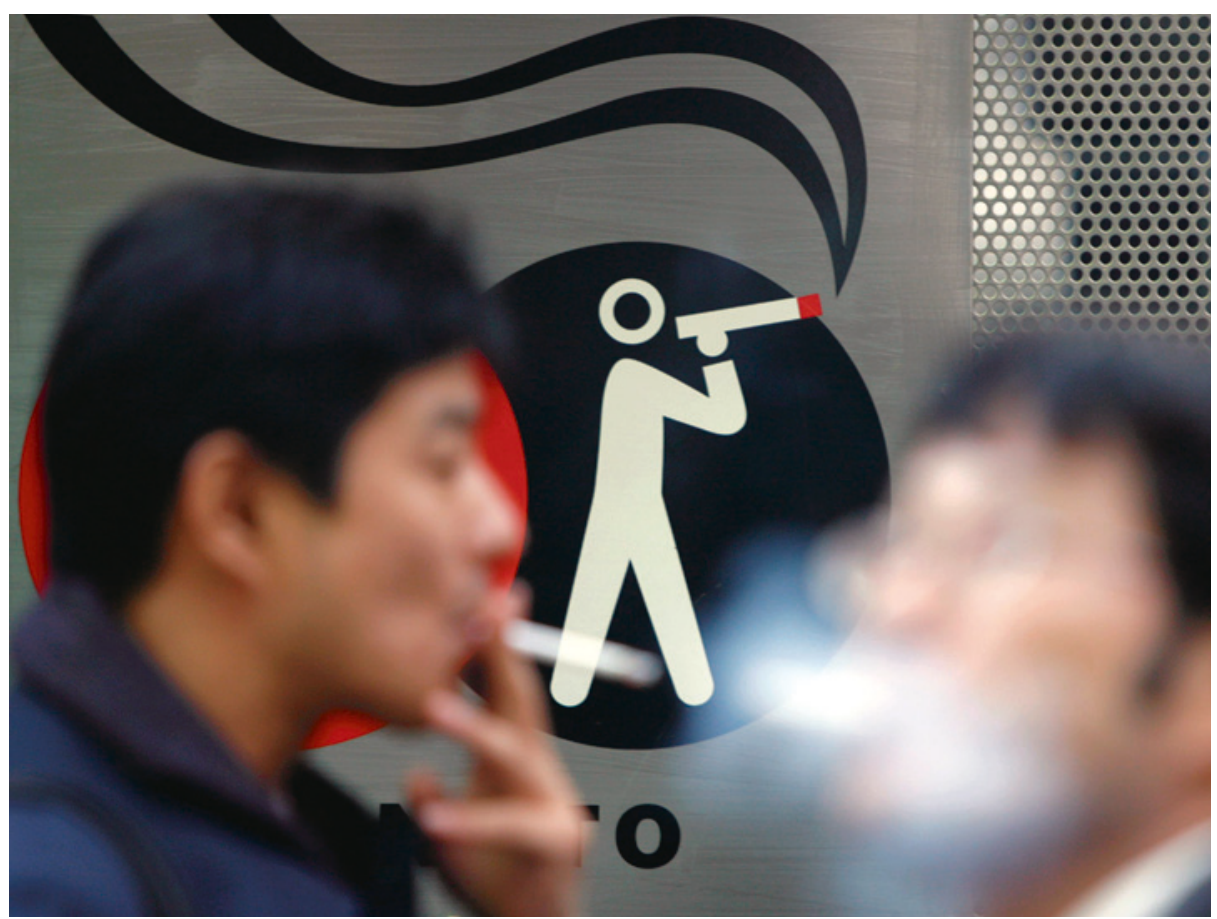

Illustrasjonsfoto: Reuters/Scanpix

I en studie fra Japan er sammenhengen mellom eksponering for tobakksrøyk i de første leveårene og karies i melketenner undersøkt (1). Studien omfattet rundt 76000 barn født i perioden 2004-10.

Rundt $55 \%$ av barna hadde minst én person i hjemmet som røyket, og rundt $7 \%$ ble eksponert direkte for tobakksrøyk. Risikoen for karies i melketenner ved tre års alder var rundt $14 \%$ for barn fra hjem hvor ingen røyket da barnet var fire måneder gammelt, rundt $20 \%$ for barn fra hjem med røykere som ikke røyket i barnas nærvær, og rundt $28 \%$ for barn fra hjem hvor det ble røyket i deres nærvær. Det var ingen signifikant assosiasjon mellom mødres røyking i løpet av svangerskapet og forekomst av karies hos barn ved tre års alder.
Barna som ble eksponert for tobakksrøyk, hadde på gruppenivå høyere inntak av søtsaker og sukkerholdig drikke og dårligere rutiner for tannpuss. Forfatterne konkluderer med at det offentlige helsevesenet bør sette inn tiltak for å redusere barns eksponering for passiv røyking.

\section{Matilde Risopatron Berg}

Sykehuset Innlandet, Hamar

Litteratur

1. Tanaka S, Shinzawa M, Tokumasu H et al. Secondhand smoke and incidence of dental caries in deciduous teeth among children in Japan: population based retrospective cohort study. BMJ 2015; 351: h5397. 